\title{
MORAL OBLIGATION AND CHANGES IN PERSONAL IDENTITY
}

\author{
Søren Holm \\ University of Manchester and University of Oslo
}

\begin{abstract}
The possibility of a human person changing personal identity raises questions concerning what the moral obligations of the new person are. Do obligations endure through a change of identity or are they extinguished? Both horns of this dilemma create philosophical and practical problems. In this paper I will argue that many relational obligations do bridge changes in personal identity. I first consider two analogies of human personal change, e.g. changes in legal personality of companies and issues in state succession. In both cases relational obligations bridge a change of legal personality. I then argue that a wide range of relational obligations similarly survive in the case of changes in human personal identity, and that holding this view does not commit us to a problematic ontology of obligations.
\end{abstract}

Keywords: personal identity, change in identity, enduring obligations, interpersonal obligations, relationships

DOI: $10.3176 /$ tr.2011.2.06

\section{Introduction}

Many accounts of personal identity entail the possibility that a human being may change personal identity. ${ }^{1}$ This possibility has been claimed to cause significant problems for our ideas about interpersonal moral obligations (see for instance the essays in Mathews, Bok, and Rabins 2009). If I have an enduring moral obligation to person $\mathrm{A}$ and he has at some later time turned into person $\mathrm{B}$ do I still have that obligation? Or conversely, if person A had an enduring obligation towards me, does person B now have that obligation?

1 The most prominent of these is probably Derek Parfit's account of personal identity as identity based on overlapping ties of psychological connectedness (Parfit 1986). 
If we posit that obligations owed and held bridge changes in personal identity we seem committed to deny that these obligations are owed to and held by specific individuals thus possibly committing ourselves to the existence of 'free floating' moral obligations, or committed to positing some mechanism by which these obligations are automatically transferred to successor persons. And if we posit that they do not bridge such changes we seem committed to a range of counterintuitive implications, because the person B coming into being would not be embedded in any network of interpersonal obligations.

But are we committed to one of the horns of this dilemma? And if we are, do we thereby commit ourselves to embarrassing implications?

It is often claimed that one reason why these issues are seen as puzzling is that we only have limited experiences with persons changing identity. Our intuitions are therefore weak, and our normative frameworks not well developed.

But I will show that we do in fact frequently experience person-like entities that change identity and that we have well developed normative frameworks for deciding which obligations are owed to and held by such entities after their change of identity. I will also show how these normative frameworks can be transferred from their current context to changes in personal identity. These normative frameworks are found in law, but as I hope to show they are not without moral justification.

\section{Changes of personal identity and the law - two examples}

In law firms, states and other organisations have legal personality. They are legal subjects capable of both holding and being owed legal obligations. Just as I may owe you money I may owe my bank money. And just as you may have an obligation not to harm me, a particular state may have such an obligation.

Entities with legal personality come into existence at a certain point in time and they cease to exist at some later point in time. But they also frequently change identity through merger, break-up or acquisition. An effective legal system has to take account of these changes and has to contain rules for how these changes affect the obligations the legal persons are owed and held. Let us analyse two examples with an eye to what they can tell us about obligations and changes in human personal identity. The two examples are taken from two quite different areas of the law in order to discern whether the law has a general approach to this issue. The first example is the law relating to firms and insolvency, mergers and acquisition $^{2}$ and the second is the international law of state succession.

2 The analysis will not be jurisdictionally specific but given that a completely general analysis is impossible it will to some extent rely on English/UK company law. In the present context there is no need for jurisdictional specificity since we are merely trying to extract possible moral ideas from the law. 


\section{Here today - gone tomorrow}

Companies come into existence, merge, split, get acquired and fall into insolvency every day. They are here today, but may be gone tomorrow. But while they exist they take on obligations and they come to be owed obligations. These obligations are not unimportant. Few of us, if any can exist and flourish in modern society unless we enter into relationships of mutual obligation with companies. How does the law handle obligations held by and owed to companies which although they have bona fide legal personality often change this personality during the course of our relationship with them?

The basic principle is that unless a company is liquidated, something rather akin to being declared 'dead', the obligations it has and is owed are always transferred to one or more of its successors. A firm that buys another firm, for instance also buys all the liabilities of that firm. If car producer A buys car producer B and stops producing B's cars it cannot suddenly decide that the warranties issued by B are now invalid, because B no longer exists. And the buyers of B's cars who have borrowed money from $B$ to finance their purchase cannot claim not to owe the money anymore, because B has ceased to exist.

Similar principles apply to mergers, de-mergers and change of listed status of a company. Obligations are deemed to be permanent and there are detailed rules for apportioning them between the successors of a given firm.

Traditionally the principled stance of permanence of obligations only applied to the firm's external relations and to its financial obligations and a firm that took over another firm was at liberty to change the pay and working conditions of the existing workforce of the firm it had acquired. But even this liberty to vary obligations towards employees is now significantly curtailed in many jurisdictions. In the UK the Transfer of Undertakings (Protection of Employment) Regulations (TUPE) which first came into force in 1981 protects the rights of employees in relation to the terms and conditions of their employment, any outstanding claims (e.g. unfair dismissal or personal injury claims) and also recognition of any trade union or collective agreements affecting the employer that were in force before the transfer. The TUPE Regulations are the UK implementation of the European Community Acquired Rights Directive (77/187/EEC, as amended by Directive 98/50/EC and consolidated in 2001/23/EC) and similar implementations can be found in all the EU member states.

Liquidation of a firm does extinguish its obligations. When the liquidation process is complete all the obligations that the firm held or was owed have disappeared. A firm can be liquidated while solvent, in which case all of its financial liabilities are paid off in full before the firm ceases to exist. In the case of a solvent liquidation the firm essentially discharges all its obligations to others and thereby extricates itself from all relationships before disappearing. More commonly a firm is liquidated because it has become insolvent, i.e. unable to meet its financial obligations. In such a case an appointed insolvency practitioner will follow a set of very detailed legal guidelines in distributing whatever assets are left to those who 
have legitimate claims against the company (the Insolvency Act 1986 with later amendments).

In company law the general principle concerning obligations of a firm is thus that they are seen as permanent / invariant under conditions of change of legal personality. What is the reason for this general principle? The main reason is that in a system where change in legal personality is likely to happen obligations must be seen as permanent, because otherwise the risks of transacting with a company would be too great. If a firm could extinguish or significantly vary its obligations just by changing legal personality, few other actors would be willing to transact with the firm. If your bank could extract itself from its obligations to pay you the balance in your bank account simply by changing its legal personality, retail banking as we know it could not exist. Permanence of obligations is thus a necessity for creating stable networks of, in this case, commercial relationships.

\section{State succession and the permanence of obligations}

The law of state succession is concerned with the legal implications of states coming into existence, dividing or disappearing. What obligations do new states hold when they come into existence by secession from existing states? What obligations does a state have if it absorbs another state? Are previous treaty obligations still binding? Are treaties' automatically void or can they be renounced? Which state becomes a member of international organisations? How should the property and financial obligations be divided?

These questions had great practical importance in the 1960s during decolonisation and again in the 1990s with the breakup of the former Soviet Union and other changes in Eastern and Central Europe.

Two conventions have been proposed in order to govern this area as a matter of international law, the Vienna Convention on the Succession of States in Respect of Treaties, 1978 and the Vienna Convention on the Succession of States in Respect of State Property, Archives and Debt, 1983. Neither of these have been successful as an international legal instrument, the 1983 Convention has not yet been ratified by the 15 states that are necessary to bring it into force, and although the 1978 treaty has been ratified by 22 states and therefore is in force it has not been ratified by any of the permanent members of the UN Security Council or any members of the G20. Both conventions have thus been shunned by the rich and powerful in the international sphere.

The reason for the lack of success is primarily that the conventions affirm a distinction between 'Newly independent states' (i.e. former colonies) and other successor states and apply a so-called 'clean slate' principle to newly independent states. Article 16 of the 1978 Convention articulates this in the following way: 
PART III.

NEWLY INDEPENDENT STATES

SECTION 1. GENERAL RULE

Article 16

Position in respect of the treaties of the predecessor State

A newly independent State is not bound to maintain in force, or to become a party to, any treaty by reason only of the fact that at the date of the succession of States the treaty was in force in respect of the territory to which the succession of States relates.

This clean slate in relation to previous treaty obligations for newly independent states is only limited in relation to boundary regimes:

\section{Article 11}

Boundary regimes

A succession of States does not as such affect:

(a) a boundary established by a treaty; or

(b) obligations and rights established by a treaty and relating to the regime of a boundary.

In relation to other kinds of successor states treaty obligations remain in force as expressed in Article 34 of the 1978 Convention

\section{Article 34 \\ Succession of States in cases of separation of parts of a State}

1.When a part or parts of the territory of a State separate to form one or more States, whether or not the predecessor State continues to exist:

(a) any treaty in force at the date of the succession of States in respect of the entire territory of the predecessor State continues in force in respect of each successor State so formed;

(b) any treaty in force at the date of the succession of States in respect only of that part of the territory of the predecessor State which has become a successor State continues in force in respect of that successor State alone.

2.Paragraph 1 does not apply if:

(a) the States concerned otherwise agree; or

(b) it appears from the treaty or is otherwise established that the application of the treaty in respect of the successor State would be incompatible with the object and purpose of the treaty or would radically change the conditions for its operation.

In recent years international practice has in general rejected the clean slate principle, especially in relation to treaty obligations, and instead applied what could be called the permanence of obligations approach. The permanence approach has also mainly been applied in relation to the property and debts of states (see the work of the International Law Association - Committee on Aspects of the Law on State Succession (1994-2008) at http://www.ila-hq.org/en/committees/index.cfm/cid/11). The application of the permanence approach has taken place even though worries have been raised in academic literature about the identity and status of the new state and the status of the obligations (Craven 1998). Worries that are very similar to 
those in the literature about changes in personal identity. In some respects these worries are even more pertinent in the context of state succession since new states often come into being in direct opposition to their predecessors.

\section{Personal identity and moral obligation - Take 2}

As we have seen above, the law's general approach to changes in legal personality is to place the new entity in the same place in the framework of obligations that was previously occupied by the former entity. The new entity is taken to hold and be owed the set of obligations that the former entity held and was owed, or the relevant subset of these obligations. ${ }^{3}$ It is only if a legal person ceases to exist without remainder that the set of obligations that it holds and is owed also ceases to exist.

Why has the law developed in this way? The most important reason is that most (all?) of the relevant obligations are relational obligations. The firm or state holds obligations towards a set of identifiable others and are owed obligations by another set of identifiable others. Those others have to be able to rely on these obligations not being extinguished every time an entity changes identity. Although one entity involved in the relationship of obligation changes identity, the other stays the same.

Another reason is that the law denies that there is anything paradoxical in stating that obligations owed to or held by legal person A can transfer to a later and different legal person B if B stands in the right relationship to A. Another way to put this point is that the law has a double conceptualisation of what legal person A turning into legal person B involves. On one conceptualisation A ceases to exist and B comes into existence. On the other conceptualisation A transforms into B without remainder. A does not cease to exist but is fully incorporated into B and does in a certain sense endure. ${ }^{4}$

In what way is this helpful when discussing changes in personal identity in human beings? Let us first note where it is not helpful. Both legal examples are concerned with relational obligations and are therefore not helpful in discussions of whether a person A can bind a later person B where this binding does not involve any other persons, for instance by executing a living will or an advance directive. It will thus not tell us anything about whether we should follow an advance directive not to treat if there is no longer the right relation of personal identity between the person issuing the directive and the person now existing. ${ }^{5}$

3 A new state established by secession of part of a pre-existing state does for instance, only enter as a party to border treaties with those countries with which it has borders.

4 Signs of this enduring can be seen in the successive names of firms undergoing successive mergers.

5 We might find inspiration for discussing those kinds of issues in other areas of law such as the law of covenants relating to property, or the law relating to variations of trusts. 
But what about relational obligations? Should we conceive of them as, at least to some extent enduring when a human being changes personal identity? Except possibly for non-religious hermits all of us have relational obligations. ${ }^{6}$ Some of these obligations are legal or in other ways formalised, e.g. the legal obligations between married couples, others are exclusively moral and many are mixed.

The main objection to the idea that we should, at least as a prima facie principle assume that such relational obligations bridge changes in personal identity is that it seems to imply that the successor person has obligations that he or she has not voluntarily assumed and following "Kant ${ }^{7}$ it is often denied that moral obligations can be imposed on a person in this way. It is, for instance, a recurrent motif in arguments concerning reproductive obligations to claim that women only have obligations towards their embryos and foetuses in so far as they have either explicitly or implicitly accepted those obligations by consent or at least assent (see for instance Rhodes 1999).

But is the idea of obligations that automatically attach to someone in a specific situation or role really that strange? ${ }^{8}$ If we think that these obligations have some kind of independent ontological existence, that they are somehow already in existence just waiting for someone to attach themselves too then such obligations would truly look strange, or queer to use Mackie's terminology (Mackie 1977). But perhaps we do not need to commit ourselves to this specific ontology of obligations.

What we need is merely the claim that a person may have obligations that he or she has not voluntarily assumed and that claim does not entail an ontology of free floating obligations.

So, let us take a closer look at relational obligations and let us start on the side of the obligation where there is no change. Let us imagine that $\mathrm{P}$ promises $\mathrm{A}$ to pay him $£ 100$ in two weeks time and that both $\mathrm{P}$ and $\mathrm{A}$ know that $\mathrm{A}$ is imminently going into hospital for a kind of neurosurgery that might change personal identity. Imagine further that A's personal identity actually changes and that two weeks later a different person B exists who is the successor to A. Would it make a difference to P's moral obligation to pay the money if $\mathrm{P}$ originally promised to 'pay A' or to 'pay A or any successor person to A'? It may be helpful to consider a parallel case with which we are slightly more familiar than change of personal identity. If A had died during the operation, how would that have affected P's obligation? If A is dead P clearly cannot pay the money to A, but there are many

6 Religious hermits presumably have relations with God or the gods and have obligations within those relations.

7 I.e. the received version of Kant's philosophy.

8 It is worth noting that those consequentialists who follow Richard Hare's prescriptivist derivation of ethics are committed to the view that anyone who utters the word 'ought' in a moral sense thereby commits him or herself to all of morality including all obligations flowing from consequentialism (Hare 1952). This is a very thin sense of voluntary assumption of obligation, since the phenomenology of using 'ought' does not support the claim that most people who use the word realise the full prescriptivist implications of using it. 
circumstances where P's obligation to pay the money is not extinguished by A's death. If, for instance $\mathrm{P}$ had borrowed the money from $\mathrm{A}$ and if $\mathrm{A}$ has legitimate heirs, then $\mathrm{P}$ will in most cases still have a moral obligation to pay even if he had only promised 'to pay A'. ${ }^{9}$ So maybe the specific content of P's obligation over time is, in this case not only dependent on the exact propositional form of P's original promise but on what others, in this case A's heirs can legitimately expect.

But if $\mathrm{P}$ can have obligations to A's successors when A is dead then $\mathrm{P}$ can also have obligations to A's successors when A has changed personal identity. These are not new obligations that suddenly come into existence, but direct continuations of previous obligations. And there is not paradox in these enduring obligations perhaps having a slightly different content. Most of our moral obligations are context dependent. Exactly how we ought to discharge them depends on the specifics of the situation where we need to discharge them. The exact content of a person's parental obligations can, for instance not be exhaustively enumerated, but will depend on the contexts in which they and their child finds themselves.

What about the other side of the relational equation? This seems more puzzling. How can a new person who has come into existence following a change in personal identity be held to the obligations of the old person? But maybe the puzzle is again more apparent than real. Let us imagine that A's successor B wakes up after the operation and is about to be discharged from hospital. He asks the nurse to help him get into his clothes, but is told that he has no clothes because the clothes belonged to A, who exists no more. He is further informed that he has no property at all, no job, no social security entitlements and no wife, since all of these relied on A being in a certain relationship with other people and institutions and since he is now $\mathrm{B}$ and not $\mathrm{A}$ those relations have completely ceased to exist just as they would if A had died. Would B be justified in claiming that the nurse had got things wrong? Let us first note that it is likely that if changes in personal identity were common and occurred regularly then we would have legal rules governing the distribution of legal obligations following changes of personal identity and that it is likely that these legal rules would make B the 'heir' to many of A's entitlements and obligations. But that does not in itself settle the question of the possible endurance of moral obligations. If $\mathrm{A}$ had promised to pay $\mathrm{P} £ 100$ would B be bound by this promise? Again the case of A's death offers an illustrative parallel case. There are many cases where the obligation to pay $\mathrm{P}$ would not be extinguished by A's death but would devolve on A's heirs. And this is not a question of voluntary assumption of this obligation. Legally A's heirs might renounce their inheritance and thereby the legal obligation to pay $\mathrm{P}$. The legal obligation would then fall on A's estate and if A died insolvent P would never be paid. But this would not automatically extinguish the moral obligation of A's heirs. That obligation would continue to exist.

9 There are clearly many complications here. The strength of P's obligation to pay may, for instance depend on the kind of legitimate heir. If A dies intestate and without living relatives the state is the legitimate heir, but P's moral obligation to pay the state may not be of the same strength as his obligation to pay a personal heir of A. 
So, there is nothing strange or paradoxical in the idea that relational obligations can bridge changes of personal identity and accepting this does not commit us to a problematic ontology of obligations.

What are the practical implications of this? What the argument so far has established is that it makes sense to see relational obligations as prima facie enduring in contexts of changes of personal identity on one side of the relation. But prima facie permanence of obligations does, like all prima facie statements imply defeasibility. And this raises the question: what are the conditions under which permanence of obligations does not obtain? Part of the answer must be found in an analysis of the very many different kinds of relationships that give rise to relational obligations and the conditions under which such obligations endure through changes in the relationship when those changes are not changes in personal identity. But that is the topic of another paper.

\author{
Address: \\ Søren Holm \\ Centre for Social Ethics and Policy \\ School of Law \\ University of Manchester \\ Manchester M13 9PL, UK \\ E-mail: Soren.holm@manchester.ac.uk
}

\title{
References
}

Craven, M. C. R. (1998) "The problem of state succession and the identity of states under international law". European Journal of International Law 9, 142-162.

Hare, R. M. (1952) The language of morals. Oxford: Oxford University Press.

Mackie, J. L. (1977) Ethics - inventing right and wrong. London: Penguin.

Mathews, D., H. Bok, and P. V. Rabins, eds. (2009) Personal identity and fractured selves: perspectives from philosophy, ethics, and neuroscience. Baltimore: Johns Hopkins University Press.

Parfit, D. (1986) Reasons and persons. Oxford: Oxford University Press.

Rhodes, R. (1999) “Abortion and assent”. Cambridge Quarterly of Health Care Ethics 8, 416-427. 